\section{Original Research}

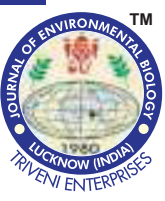

DOI : http://doi.org/10.22438/jeb/40/1/MRN-843
Journal Home page : www.jeb.co.in $\star$ E-mail : editor@jeb.co.in Journal of Environmental Biology $\mathrm{JEB}$ p-ISSN: 0254-8704 e-ISSN: 2394-0379 CODEN: JEBIDP

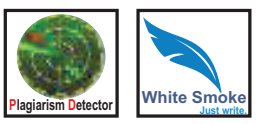

\title{
Genetic diversity of termites from Ta'if City, Saudi Arabia
}

\begin{tabular}{l}
\hline Paper received: 25.01 .2018 \\
\hline \\
Authors Info \\
N. Alotaibi $i^{1,2}$, A. Mashaly ${ }^{1,3}$, \\
R. Alajmi', A. Ahmed ${ }^{1,3}$ \\
and T. Ayaad ${ }^{4}$ \\
${ }^{1}$ Department of Zoology, \\
College of Sciences, King Saud \\
University, Riyadh-11451, \\
Saudi Arabia \\
${ }^{2}$ Department of Biology, \\
Faculty of Science, Taif University, \\
Taif-26571, Saudi Arabia \\
${ }^{3}$ Department of Zoology, \\
Faculty of Science, Minia \\
University-61519 El Minia, Egypt \\
${ }^{4}$ Department of Entomology, \\
Faculty of Science, Cairo \\
University, Orman-12613, \\
Giza, Egypt \\
\end{tabular}

*Corresponding Author Email : mashaly69@gmail.com

\section{Edited by \\ Dr. Ananda Mukhopadhyay}

\section{Reviewed by}

Professor Ola El-Habit

Dr. Placheril John
Revised received: 03.05.2018

Re-revised received: 03.07.2018

Accepted: 30.07 .2018

\begin{abstract}
Aim : In Saudi Arabia, termites are considered as notorious pests that cause enormous damage in both rural and urban areas. The diversity of termites collected from various locations in Ta'if City were characterized, based on the mitochondrial genes mt12S rRNA, mtCOI and $m+C O I I$.

Methodology : Termite samples were manually collected during the spring of 2016 from different areas. Five different areas were surveyed to cover all regions of Ta'if City. Molecular identification method was applied to study genetic diversity of termite.

Results : A total of 2229 termites were identified as eight species from three families on the basis of best gene (mt12S rRNA). Microcerotermes sp. was the most abundant species, whereas Angulitermes sp. was the least abundant with $0.8 \%$ representation. Anacanthotermes ochraceus and Microtermes sp. showed the least amount of intraspecific variation, the two species being 100\% identical. Microcerotermes arboreus showed the highest intraspecific variation, ranging from $0.0 \%$ to $4.0 \%$. Interspecific variability between the collected and identified species ranged from $7 \%$ to $21 \%$.
\end{abstract}

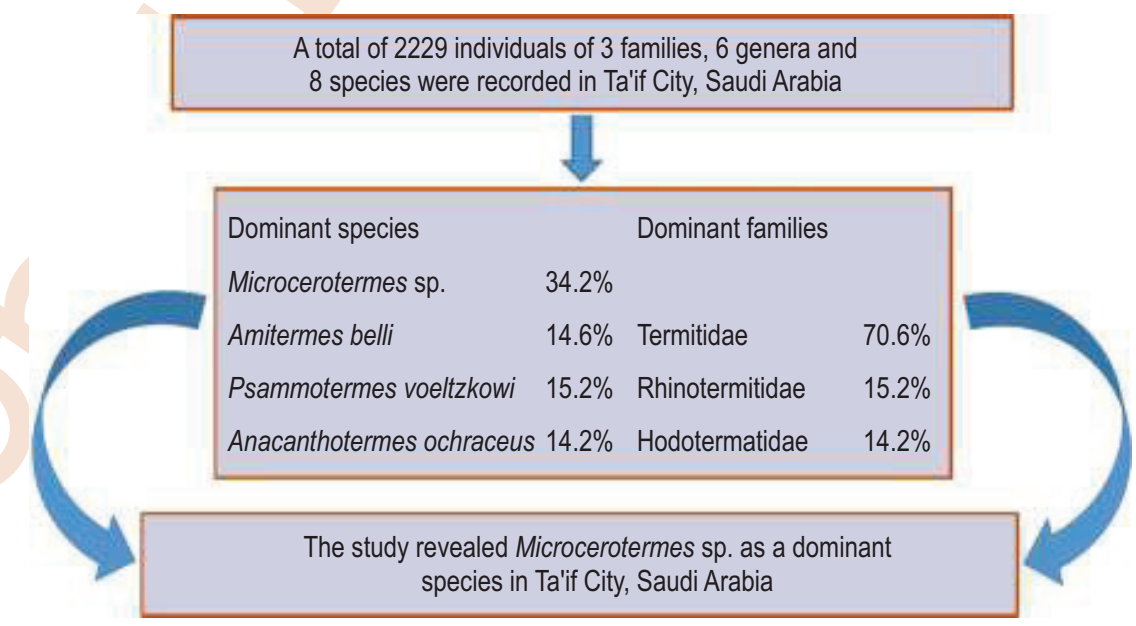

Interpretation : The results indicated the presence of eight different species of termites and the possibility of three new species based on genetic data.

Key words: Genetic diversity, Phylogeny, SaudiArabia, Termites

How to cite: Alotaibi, N., A. Mashaly, R. Alajmi, A. Ahmed and T. Ayaad: Genetic diversity of termites from Ta'if City, Saudi Arabia. J. Environ. Biol., 40, 29-35 (2019). 


\section{Introduction}

Termites (Blattodea: Isoptera) are classified as social insects, which are well known for sharing of resources, cooperation in rearing offspring, division of labor and overlapping generations (Suiter et al., 2002). They represent high proportion of soil insect biomass (Roy et al., 2006). Termites are phylogenetically separated in to two groups: the lower termites (Mastotermitidae, Kalotermitidae, Hodotermitidae, Rhinotermitidae, and Sternitermitidae) and the more advanced higher termites (Termitidae). Termitidae is known to be the largest of the termite families, comprising approximately $85 \%$ of all known genera and nearly $70 \%$ of the known species (Ohkuma et al., 2003). Termites can be grouped into four ecological types viz. dry wood, damp wood, harvester and subterranean termites (Nutting and Jones, 1990), based primarily on where they live and the food they consume. Only the subterranean termites require continued contact with soil to complement their water and moisture needs. These subterranean social insects are mostly found in temperate climates and are considered to be of economic importance with respect to agriculture (Wang et al., 2009; Jayashree et al., 2014). Termites cause heavy destruction of agricultural crops and buildings, resulting in severe economic losses, as they feed on wood, timber and a wide range of secondary products (Kumari et al., 2009). In contrast, termites are often referred to as "ecosystem engineers" (Jouquet et al., 2006) as they play a vital role in the recycling of plant materials and wood, in modifying and improving soil conditions and composition and in providing food for other animals (Kambhampati and Eggleton, 2000). They are also considered to be potent catalysts due to their role in converting lignocellulose into biofuels (Manjula et al., 2011), which is of potential industrial value.

The effective control of these pests require different control measures depending on the target species, and thus relies heavily upon accurate species identification (Austin et al., 2004). Ecological and biological studies, however, face problems in determining correct and accurate taxonomic identification of species due to lack of experts on many genera and species of termites, particularly when dealing with newly discovered species or their siblings. Furthermore, the ambiguity of termite morphological characteristics and the social structure of these insects increase the difficulty of accurate identification based on morphological characters (Kirton, 2005). The lack of accurate taxonomic keys is currently a major problem limiting effective termite control measures.

Although, most termites are traditionally identified based on the morphological characteristics, molecular technologies, DNA, chromosomes, karyotyping, microarrays, PCR; and genetic markers have recently been adopted on a large scale to document phylogenetic relationships and accelerate the identification rate of termite species (Donovan et al., 2000). These molecular tools can be used in tandem with morphological characters to identify termites, as well as to determine the evolutionary relationships between different species. They may also contribute to estimate genetic differentiation within each species at the local population level. In this context, several nuclear and mitochondrial genes have been used to identify termite species in different regions (Singla et al., 2013). Generally, the mitochondrial genome (mtDNA) of animals is a better target for identification than the nuclear genome because of its high copy number, lack of introns, limited exposure to recombination and haploid mode of inheritance (Hebert et al., 2003). Accordingly, mtDNA analyses have an increased likelihood of generating species-specific markers (Harvey et al., 2003). The mitochondrial rRNA small subunit $12 S$ (12S rRNA) gene is highly conserved, and has been employed for phylogenetic analyses at higher taxonomical levels, such as in phyla or subphyla, because of its slow evolutionary rate, as well as availability of universal insect primers and ease of reliable PCR amplification (Singla et al., 2013).

In India, 12S rRNA was applied to identify the termites (Singla et al., 2013; Murthy et al., 2015). The mitochondrial cytochrome oxidase subunit I ( $\mathrm{mtCOI})$ gene, the sequence of which is mainly conserved at the species level (Hebert et al., 2003), is used for accurate species identification. Singla et al. (2015) studied mtCOI sequences of nine termite species and established the phylogenetic tree, they showed a state of genetic evolution of the Indian termites with each other and from different geographical regions. The mitochondrial cytochrome oxidase subunit II (mtCOII) gene has been the most successful and widely used for studies on molecular phylogeny, species specialization, population inheritance and variation, as well as biogeography to classify termites (Long et al., 2009). Garrick et al. (2015) identified five different species of the genus Reticulitermes using mt COII gene in the southern United States, where these species could not be earlier identified by morphological characteristics.

Termites are described as the most destructive pests of various human valued properties in Saudi Arabia. Recent surveys have shown that termite diversity is on the rise (Faragalla et al., 2015). Techniques such as molecular DNA markers have not been fully used in studying of termite diversity. The present study was conducted with the aim to accurately and reliably identify termites in Ta'if City, by using the mt12S rRNA, mtCOI and mtCOll genes.

\section{Materials and Methods}

Survey of termites and collection of samples : The survey was carried out in different geographical locations of Ta'if City, Saudi Arabia. Ta'if is located in western Saudi Arabia on the eastern slopes of the Sarwat Mountains at an altitude of $1700 \mathrm{~m}$ above sea level, increasing to $2500 \mathrm{~m}$ as one heads towards the west and south. The city has a mild climate with hot summers $\left(20^{\circ} \mathrm{C}\right.$ $\left.32^{\circ} \mathrm{C}\right)$, and cool winters $\left(8^{\circ} \mathrm{C}\right)$ (Abdou, 2014). Termite samples were collected during the spring of 2016 from different regions of the City: Al-Arfa (northern region), Hada (western region), Sedira (southern region) Saisad (eastern region) and Kaldiah (central region). In each area, samples were collected over the course of a 
day in two periods: morning hours (5-8 a.m.) and before sunset (4-6 p.m.). Termites were collected from wood buried in soil by shaking the contents of the wood into a large container. Using a soft brush, all specimens were collected without dust and transferred to plastic containers, making a note of all data relating to the location and date of collection on each container. These termites were then placed into separate sterile tubes containing absolute ethanol and stored at $-20^{\circ} \mathrm{C}$ until used. All collected insects were preliminarily identified using the morphological taxonomic keys prepared by Scheffrahn et al. (1999), and were subsequently confirmed at the Angela Marmont Centre for UK Biodiversity. The termite specimens were then preserved for subsequent molecular identification.

Isolation of total genomic DNA : Preserved termite individuals (2229 workers) were prepared for DNA extraction. Total genomic DNA was extracted using DNeasy tissue kits (Qiagen, Valencia, CA) according to the manufacturer's instructions. The concentration and purity of the extracted DNA was determined using a NanoDrop 2000 UV-Vis Spectrophotometer (Thermo Fisher Scientific Inc., USA). The extracted DNA was stored at $-20^{\circ} \mathrm{C}$ for further use.

PCR amplification and agarose gel electrophoresis: Amplification of $12 \mathrm{~S}$ rRNA, COI, and COll mitochondrial genes was carried out by polymerase chain reaction (PCR) using the primers 12S-F (SR-J-14199) (5'-TACTATGTTACGACTTAT-3') and 12S-R (SR-N-14594) (5'-AAACTAGGATTAGATACCC-3') for amplification of the mt12S rRNA gene (Murthy et al., 2015), LC01490-1-F (5'-GGTCAACAAATCATAAAGATATTGG-3') and HCO2198-R (5'-TAAACTTCAGGGTGACCAAAAAATCA$\left.3^{\prime}\right)$ for amplification of the mtCOI gene (Folmer et al., 1994), and C2F2 (5'-ATACCTCGACGWTATTCAGA-3') and TKN3785 (5'GTTTAAGAGACCAGTACTTG-3') for amplification of the mtCOll gene (Yeap et al., 2007). The PCR master mix amplification was carried out in a thermo-cycler (Applied Biosystems, USA), under the following conditions: a predenaturation step at $94^{\circ} \mathrm{C}$ for 15 min followed by 35 cycles of denaturation $\left(95^{\circ} \mathrm{C}\right.$ for $\left.45 \mathrm{sec}\right)$, annealing $\left(41,40\right.$, and $52^{\circ} \mathrm{C}$ for $45 \mathrm{sec})$, and extension $\left(72^{\circ} \mathrm{C}\right.$ for $\left.45 \mathrm{sec}\right)$, and a final extension at $72^{\circ} \mathrm{C}$ for $10 \mathrm{~min}$. The PCR products were then analyzed using $1.5 \%$ agarose gel with a $100 \mathrm{bp}$ DNA ladder (Solis
Biodyne). Gels were visualized using a gel documentation system and results were documented.

Sequencing and Bioinformatics analysis: The resulting PCR products were sent to the central lab in the College of Sciences, King Saud University, female section, for sequencing using a Big Dye Terminator V3.1 sequencing kit (Applera, Foster City, $\mathrm{CA})$. The results were analyzed using an $\mathrm{ABI} 3700$ DNA Analyzer (Applied Biosystems, Foster City, CA). Sequences were trimmed to $\sim 370 \mathrm{bp}$ and were then aligned with the respective reference species using BioEdit Sequence Alignment Editor version 7.2.5, and with the ClustalW Multiple Alignment program with a maximum number of 1,000 iterations (Thompson et al., 1994). The resulting sequences were edited to discard ambiguous bases, and the edited sequences were then aligned using the Basic Local Alignment Search Tool (BLAST), with sequences of the same or related genera retrieved from the PUBMED nucleotide database of the National Centre for Biotechnology Information (NCBI). The $\mathrm{mt} 12 \mathrm{~S}$ rRNA, mtCOI and mtCOII nucleotide sequences of each termite individual included in the present study were aligned and compared with the same species obtained from PUBMED, using ClustalW alignment (Thompson et al., 1994), where the most closely related sequence present in GenBank was used as a reference for the same species obtained in this study.

Phylogenetic analysis: A phylogenetic tree was constructed using the character-based Maximum-Likelihood method based on the Tamura-Nei model (Tamura and Nei, 1993). The MEGA-6 bioinformatics tool was used to construct the phylogenetic tree and the genetic relatedness between the isolates was analyzed. Bootstrap analysis using 1000 iterations was performed to determine the accuracy of the phylogeny. The constructed phylogenetic tree was visualized using a tree viewer program (MEGA-6).

\section{Results and Discussion}

A total of 2229 termite workers were collected in the present study from Ta'if city of Saudi Arabia. The highest density of termite individuals were collected from the northern (816) and southern regions (834), whereas, 497 termite were collected from

Table 1 : Species composition of termites collected in Ta'if based on 12S rRNA gene, intraspecific variation percentage between species, accession numbers for species and reference accession from Gene Bank

\begin{tabular}{lllll}
\hline Family & Species & $\begin{array}{l}\text { Intraspecific } \\
\text { variations \% }\end{array}$ & $\begin{array}{l}\text { Accession numbers } \\
\text { for species }\end{array}$ & $\begin{array}{l}\text { Reference accession } \\
\text { from Gen Bank }\end{array}$ \\
\hline Termitidae & Microcerotermes sp. & $0-2$ & MG197791 & DQ441732.1 \\
& Microcerotermes arboreus & $0-4$ & MG197792 & DQ441734.1 \\
& Amitermes belli & $0-2$ & MG197793 & KR078330.1 \\
& Amitermes evuncifer & $0-1$ & MG197794 & DQ441626.1 \\
& Angulitermes sp. & $0-1$ & MG197795 & DQ441634.1 \\
& Microtermes sp. & 0 & MG197796 & DQ441731.1 \\
Rhinotermitidae & Psammotermes voeltzkowi & $0-3$ & MG197797 & DQ441804.1 \\
Hodotermatidae & Anacanthotermes ochraceus & 0 & MG197798 & DQ441629.1 \\
\hline
\end{tabular}


Table 2 : Species composition of termites collected in Ta'if based on mtCOI and mtCOII genes, reference accession from Gene Bank

\begin{tabular}{llll}
\hline Gene used & Family & Species & Reference accession from Gene Bank \\
\hline $\mathrm{mtCOI}$ & Termitidae & Microcerotermes sp. & JF923261.1 \\
& & Amitermes evuncifer & AY127718.1 \\
& Termitidae & Microtermes sp. & JF923356.1 \\
& & Microcerotermes sp. & DQ923250.1 \\
& & Amitermes evuncifer & DQ442066.1 \\
& & Angulitermes sp. & JF923188.1 \\
& Rhinotermitidae & Microtermes sp. & DQ442232.1 \\
& & Psammotermes voeltzkowi & \\
\hline
\end{tabular}

the western region and only 82 individuals were found in the central region. After morphological identification and DNA isolation, the target genes in the present study (mt12S rRNA, $\mathrm{mtCO}$ and mtCOII) were amplified using PCR. For most specimens, amplified fragment of 430,700 , and 1000 bp were obtained for the mt12S rRNA, mtCOI, and mtCOll genes, respectively. All sequences were identified using the $\mathrm{NCBI}$ BLAST tool and then aligned with the sequences of other termites from GenBank to confirm molecular identification.

Molecular genetic techniques are being increasingly utilized to investigate termite biology, and these techniques enable clarification of systematics and taxonomy, an understanding of caste differentiation, identification of species and surveillance of invasive species, discovery of the relationships between populations, and unravelling of the family structure within colonies (Vargo and Husseneder, 2009). Taxonomical studies of termites are based on their phylogeny using both morphological and molecular characters (Kambhampati et al., 1996; Donovan et al., 2000; Austin et al., 2012), and DNA sequence data has already been used to identify subterranean termites (Smith et al., 2010). Results based on the mt12S rRNA gene showed that the collected termites belong to eight species across three families, with one species
(Psammotermes voeltzkowi) belonging to the family Rhinotermitidae, six species (Microcerotermes sp. M. arboreus, Amitermes belli, Am. evuncifer, Angulitermes sp., and Microtermes sp.) belonging to the family Termitidae, and one species (Anacanthotermes ochraceus) belonging to the family Hodotermatidae (Table 1). However, based on the mtCOI gene, the termite specimens were identified to only three species, namely, Microcerotermes sp., Am. evuncifer and Microtermes sp., in the family Termitidae (Table 2). On the basis of mtCOII gene analysis, termite specimens were identified to belong to two families: family Rhinotermitidae, represented by one species ( $P$. voeltzkowi), and family Termitidae represented by four species (Microcerotermes sp., Am. evuncifer, Angulitermes sp. and Microtermes sp.)

The data shown in Table 3 indicate that, in addition to accounting for the highest number of individuals collected, both northern and southern regions had the highest species richness, with the same four species (Microcerotermes sp., A. ochraceus, $P$. voeltzkowi, and Amitermes sp.) being collected from each region. Two species were identified from each of the western (Microtermes sp. and Microcerotermes sp.) and central regions (Angulitermes sp. and Microcerotermes sp.), respectively. Among the 2229 termite workers collected, Microcerotermes sp. was the most abundant species, representing $34.2 \%$ of the total

Table 3 : Abundance of species in different regions of Ta'if City

\begin{tabular}{llll}
\hline Region & No. of collected specimens & Species Abundance & Species \\
\hline North region & 816 & 4 & $\begin{array}{l}\text { Microcerotermes sp. } \\
\text { Anacanthotermesochraceus } \\
\text { Psammotermesvoeltzkowi } \\
\text { Amitermesevuncifer }\end{array}$ \\
South region & 834 & & $\begin{array}{l}\text { Microcerotermsarboreus } \\
\text { Anacanthotermesochraceus } \\
\text { Psammotermesvoeltzkowi }\end{array}$ \\
West region & 4 & Amitermes belli \\
East region & 497 & & Microtermes sp. \\
Central region & - & 2 & Microcerotermes sp. \\
Total & 82 & - & Microcerotermes sp. \\
Angulitermes sp.
\end{tabular}


Table 4 : Species composition and relative abundance of collected termite species in Ta'if

\begin{tabular}{llll}
\hline Family & Species & No. of termites & Percentage (\%) \\
\hline Termitidae & Microcerotermes sp. & 764 & 34.2 \\
& Microcerotermesarboreus & 200 & 8.9 \\
& Amitermes belli & 326 & 14.6 \\
& Amitermesevuncifer & 67 & 3.3 \\
& Angulitermes sp. & 18 & 0.8 \\
Rhinotermitidae & Microtermes sp. & 197 & 8.8 \\
Hodotermatidae & Psammotermesvoeltzkowi & 340 & 15.2 \\
\hline
\end{tabular}

specimens, whereas Angulitermes sp. was the least abundant species, accounting for only $0.8 \%$ individuals (Table 4 ). Termites were collected from different regions of Ta'if City, and this indicates that climatic factors and the nature of soil in these areas are suitable for termites such as Microcerotermes sp. which was found in different areas with variable conditions, and was recorded at the highest abundance among the collected samples. Furthermore, A. ochraceus, Amitermes sp. and P. voeltzkowi were collected from the same localities, which indicates that they share a preference for similar conditions of temperature, landform, rainfall and vegetation, and that the northern and southern regions of Ta'if City, which are characterized by high temperatures, a few desert plants, and sandy soil, provide suitable conditions for these species (Moawad et al., 2015). In contrast, Angulitermes sp., which was the least abundant species collected in the present study, was found in only one area (the central region), indicating that the distribution of this species is generally very limited (Moawad et al., 2015). Similarly, Microtermes sp. was found only in the western region of Ta'if City, which is characterized by the conditions (low temperature, wet soil, and abundant vegetation) preferred by this species (Moawad et al., 2015). No termites, however, were detected in the eastern region of the city, and this could be explained by the extensive construction and demolition activity characterizing this region, making the area unsuitable for termite habitation and leading to temporary disappearance from the region (Reid, 2009).

As the mt12S rRNA has proved to be a useful molecular marker for better identification of termites on the species level and variability among species, one sequence from each species was

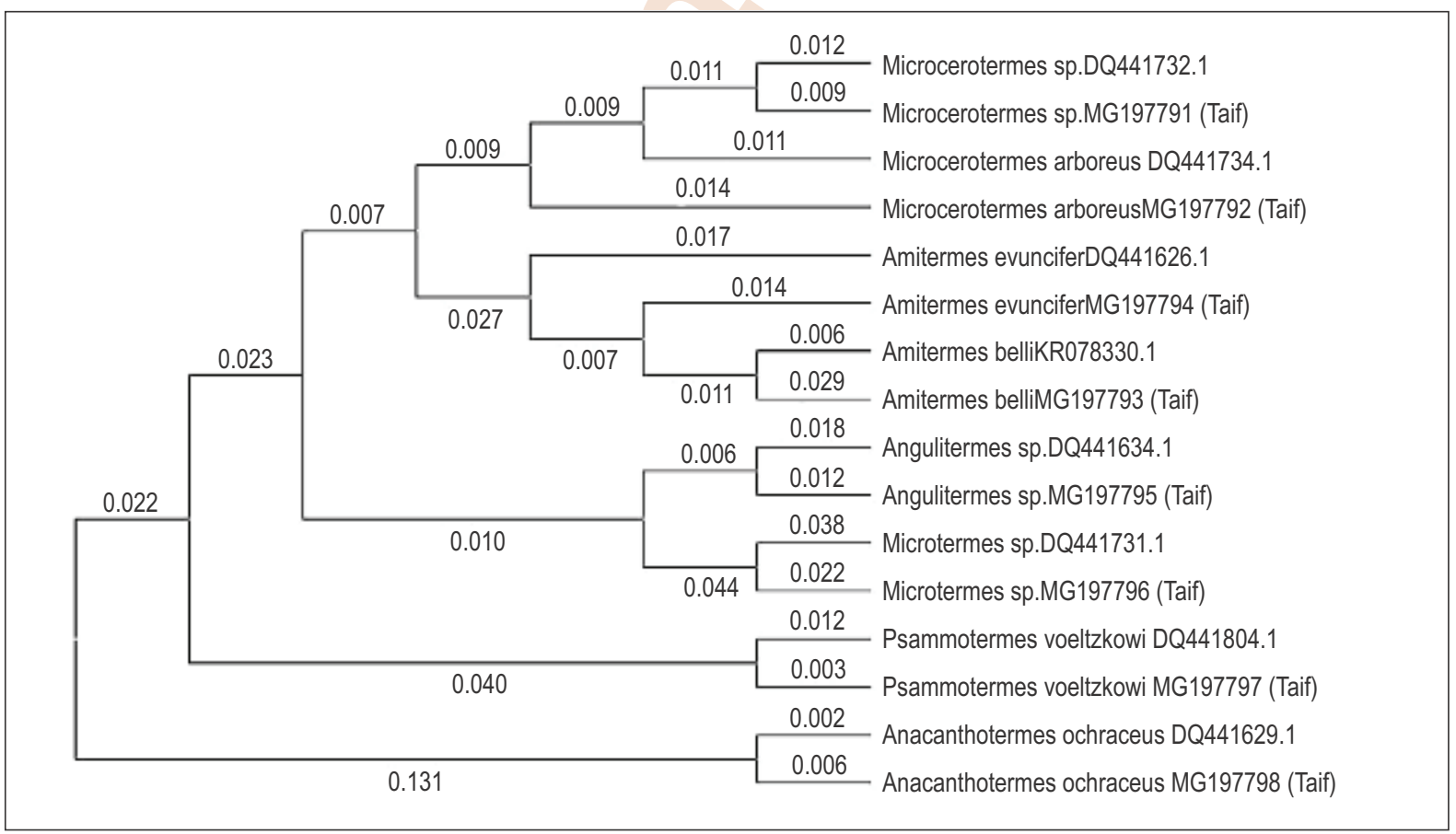

Fig. 1 : Maximum-likelihood phylogenetic tree of termite species inferred from a 12S rRNA gene fragment. 
selected and submitted in GenBank with the accession numbers shown in Table 1. The mt12S rRNA gene sequence results were used to study intra-and-interspecific variations and the genetic relationships between identified species through the construction of a phylogenetic tree. Examination of the intraspecific variation of termite species based on the mt12S rRNA gene indicated that $A$. ochraceus and Microtermes sp. showed the lowest variation, with all individuals of these two species being $100 \%$ identical. In contrast, $M$. arboreus specimens showed the highest intraspecific variations, ranging from $0.0 \%$ to $4.0 \%$. The intraspecific variations of the remaining species were between $0 \%$ and $3 \%$ (Table 1 ).

This result is consistent with the standard established by Hebert et al. (2003). Further, other previous studies have reported that the genetic diversity between individuals of the same species ranges between $0.0 \%$ to $0.51 \%$ (Austin et al., 2012; Firouzabadi et al., 2012). According to Hebert et al. (2003) divergence between different species is expected to be greater than $3 \%$, and in the present study it was found that interspecific variation between the termites ranged between $7 \%$ to $21 \%$. The constructed phylogenetic tree showed that the Hodotermitidae family is genetically distant from the other families examined in the present study, which is consistent with the species belonging to this family are considered to be harvester termites, whereas those in the other families are considered to be subterranean termites (Faragalla and Alqhtani, 2013).

A phylogenetic tree was constructed using the MaximumLikelihood method based on multiple sequence alignments of the mt12S rRNA gene. The phylogenetic tree showed that the collected termite specimens were divided into two clades. The major clade consisted of two families, Termitidae (represented by species of Microcerotermes, Amitermes, Angulitermes and Microtermes) and Rhinotermitidae (represented by $P$. voeltzkowi), wheras minor clade constituted the family Hodotermitidae represented by $A$. ochraceus (Fig. 1). The relationships determined from the phylogenetic tree were consistent with the morphological and molecular identifications, which indicated that the genetic divergence between Microcerotermes and Amitermes was less than that between Microcerotermes and Angulitermes, whereas the divergence between Microtermes and Microcerotermes was greater than that between Angulitermes and Amitermes. Finally, the genetic divergence between Rhinotermitidae and Termitidae was less than that between Hodotermitidae and Termitidae.

Our report here represents a preliminary analysis of the phylogenetic relationships among six genera of termites belonging to three families. Examination of all the termite specimens based on a partial sequence of the 12S rRNA gene showed a PCR product with a band of $430 \mathrm{bp}$ in length, which is similar to that obtained by Singla et al. (2013) using the same primers. In contrast, using the same primers, Murthy et al. (2015) obtained a band of $650 \mathrm{bp}$. PCR results for amplification of the $\mathrm{mtCO}$ gene showed a band of $700 \mathrm{bp}$ in length, which differed from that obtained by Folmer et al. (1994), whereas the PCR product of the mtCOII gene gave a band of $1000 \mathrm{bp}$ in length, which similarly differed from that obtained by Yeap et al. (2010). These discrepancies indicate that these previous authors had examined different termite species. Further, sequences of the obtained PCR products were identified using the BLAST tool according to Singla et al. (2013) and Murthy et al. (2015). Results based on mt12S rRNA gene analysis showed eight species belonging to three families (Table 1).

On the basis of morphological identification, Moawad et al. (2015) identified the same genera in Ta'if City, although with different species complements. Faragalla et al. (2015) conducted DNA fingerprinting of different genera, including Anacanthotermes, Psammotermes and Microtermes in Jeddah City, Saudi Arabia. Molecular identification based on the mtCOI gene did not match the morphological identification of termite specimens because it could not identify some species, namely, M. arboreus, Am. belli, $P$. voeltzkowi, Angulitermes sp. and A. ochraceus. Although the $\mathrm{mtCO}$ gene has potential for rapid and accurate identification of insects, this gene does not reliably distinguish among some recently diverged species, as seen in the present study and also demonstrated by Vanegas and Agnarsson (2017). Molecular identification based on the mtCOII gene gave better results based $\mathrm{mtCO}$, in that its identification of five species was consistent with the morphological identifications, although it was unable to identify the species A. ochraceus, M. Arboreus and Am. belli.

In conclusion, this study indicates that the termite mt12S rRNA gene sequence is a good marker for determining and differentiating between different termite species. The results obtained can be utilized to study the termite's systematics in Saudi Arabia. In addition, further studies should be conducted to attain species-level identification for some of the identified genera.

\section{Acknowledgments}

Authors thank King Abdulaziz City for Science and Technology for the financial a grant (No. 0031-001-01-17-1). Also, we thank the Deanship of Scientific Research and RSSU, King Saud University for the technical support offered.

\section{References}

Abdou, A.E. : Recent trends in surface air temperature over Al-Taif, Saudi Arabia. IJSR., 3, 2319-7064 (2014).

Austin, J.W., A.L. Szalanski, R.E. Gold and B.T. Foster : Genetic variation and geographical distribution of the subterranean termite genus Reticulitermes in Texas. Southwest Entomol., 29, 1-11 (2004).

Austin, J.W., A.L. Szalanski, C. Solorzano, R. Magnus and R.H. Scheffrahn : Mitochondrial DNA genetic diversity of the drywood termites Incisitermes minor and I. snyderi (Isoptera: Kalotermitidae). Florida Entomol., 95, 75-81 (2012).

Donovan, S.E., D.T. Jones, W.A. Sands and P. Eggleton : Morphological phylogenetics of termites (Isoptera). Biol. J. Linn. Soc., 70, 467$513(2000)$.

Faragalla, A.A. and M.H. Alqhtani: The urban termite fauna (Isoptera) of Jeddah City, Western Saudi Arabia. Sci. J., 10, 1695-1701 (2013).

Faragalla, A.A., M.H. Alqhtani and M.M. Ahmed : DNA fingerprinting of 
some major genera of subterranean termites (Isoptera) (Anacanthotermes, Psammotermes and Microtermes) from Western Saudi Arabia. Acad. J. Entomol., 8, 104-109 (2015).

Firouzabadi, E.A., B. Habibpour, H. Galehdari and P. Shishehbor: Genetic diversity and morphometric study of thirteen populations of Microcerotermes diversus (Silvestri) (Isoptera: Termitidae) in southern Iran. Proceedings IRG Annual Meeting (ISSN 20008953). IRG (2012).

Folmer, O., M. Black, W. Hoeh, R. Lutz and R. Vrijenhoek : DNA primers for amplification of mitochondrial cytochrome $C$ oxidase subunit I from diverse metazoan invertebrates. Mol. Mar. Biol. Biotechnol., 3, 294-299 (1994).

Garrick, C., D. Collins, N. Yi, J. Dyer and J. Dyer : Identification of Eastern United States reticulitermes termite species via PCR-RFLP assessed using training and test data. Insects, 6, 524-537 (2015).

Harvey, M., R.I. Dadour, S. Gaudieri, M.W. Mansell and M.H. Villet : mtDNA - based identification of blowflies in forensic entomology: More accurate postmortem interval estimation and beyond. Foren. Sci. Int., 136, 389 (2003).

Hebert, P.D., A. Cywinska, S.L. Ball and J.R. Waard : Biological identifications through DNA barcodes. Proc. Biol. Sci., 270, 313-321 (2003).

Jayashree, S., J. Rathinamala and P. Lakshmanaperumalsamy : Antitermite properties of root and leaf powder of vetiver grass. J. Env. Biol., 35, 193-196 (2014).

Jouquet, P., J. Dauber, J. Lagerlo, P. Lavelle and M. Lepage: Soil invertebrates as ecosystem engineers: Intended and accidental effects on soil and feedback loops. App/ Soil Ecol., 32, 153-164 (2006).

Kambhampati, S. and P. Eggleton : Taxonomy and phylogeny of termites. (Eds.: In T. Abe, D. Bignell, and M. Higashi) Termites: In: Evolution, Sociality, Symbioses, Ecology. Dordrecht: Kluwer Academic Publishers, pp. 1-23 (2000)

Kambhampati, S., K.M. Kjer and B.L. Thorne : Phylogenetic relationship among termite families based on DNA sequence of mitochondrial 16S ribosomal RNAgene. Insect Mol. Biol., 5, 229-238 (1996).

Kirton, L.G. : Proceedings of the fifth international conference on Urban Pests (Eds.). Chow-Yang Lee and $\mathrm{H}$ William Robinson (editing), Malaysia (2005).

Kumari, M., V.L. Sharma, M. Sodhi, M. Mukesh, Y. Shouche and R.C. Sobti: PCR-SSCP and sequence analysis of three Odontotermes spp. (Order: Isoptera; Family: Termitidae) on the basis of partial 16S rRNAgene. Mol. Cell. Biochem., 330, 153-162 (2009).

Long, Y., H. Xiang, L. Xie, X. Yan, M. Fan and Q. Wang: Intra-and interspecific analysis of genetic diversity and phylogeny of termites in East China detected by ISSR and COII markers. Sociobiology, 53, 411-430 (2009).

Manjula, A., S. Satyavathi, P. Gunasekaran and J. Rajendhran: Comparison of seven methods of DNA extraction from termitarium for functional metagenomics DNA library construction. J. Sci. Ind. Res., 70, 945-951 (2011).

Moawad, S.S., A.F. Al Barty and N.G. Al-Otabie: Survey and classification of some termites' species in some arid area. J. Adv. Agr., 4, 383-391 (2015).

Murthy, S.K., R. Rajeshwari, S.L. Ramya, T. Venkatesan, S.K. Jalali and
A. Verghese: Genetic diversity among Indian termites based on mitochondrial 12S rRNAgene. Eur. J. Zool. Res., 4, 1-6 (2015).

Nutting, W.L. and S.C. Jones : Methods for studying the ecology of subterranean termites. Sociobiology, 17,167-189 (1990).

Ohkuma, M., H. Yuzawa, W. Amornsak, Y. Sornnuwat, Y. Takematsu, A. Yamada, C. Vongkaluang, O. Sarnthoy, N. Kirtibutr, N. Noparatnaraporn, T. Kudo and T. Inoue: Molecular phylogeny of Asian termite (Isoptera) of the families Termitidae and Rhinotermitidae based on mitochondrial COll sequences. Mol. Phylogen. Evol., 31, 701-710 (2003).

Reid, A. : Termite risks to houses in Australia. Struct Surv., 27, 200-209 (2009).

Roy, V., C. Demanche, A. Livet and M. Harry : Genetic differentiation in the soil-feeding termite Cubitermes sp. affinis subarquatus: Occurrence of cryptic species revealed by nuclear and mitochondrial markers. BMC Evol. Biol., 6,102 (2006).

Scheffrahn, R.H., N.Y. Su and J.R. Mangld : Amitermes amicki, a new subterranean termite (Isoptera: Termitidae, Termitinae) from aruba. Florida Entomol., 82, 7-14 (1999).

Singla, M., V.L. Sharma, R.C. Sobti, M. Sodhi and M. Kumari : Genetic relationship among Indian termites based on DNA sequence of mitochondrial 12S ribosomal RNAgene. Int. J. Evol., 2, 1-5(2013).

Singla, M., N. Goyal, C. Sobti and L. Sharma : Estimating molecular phylogeny of some Indian termites combining $\mathrm{COI}$ sequences. $\mathrm{J}$. Entomol. Zool. Sci. 3, 213-218 (2015).

Smith, A.L., M.P. Smith and B.M. Kard : Oklahoma formosan subterranean termite surveillance program and termite survey (Isoptera: Rhinotermitidae, Termitidae). J. Kansas Entomol. Soc., 83, 248-259 (2010).

Suiter, D.R., S.C. Jones and B.T. Forschler : Biology of subterranean termites in the eastern United States. University of Georgia Cooperative Extension Service Bulletin, 1225, p.16 (2002).

Tamura, K. and M. Nei: Estimation of the number of nucleotide substitutions in the control region of mitochondrial DNA in humans and chimpanzees. Mol. Biol. Evol., 10, 512-526 (1993).

Thompson, J.D., D.G. Higgins and T.J. Gibson : CLUSTAL W: Improving the sensitivity of progressive multiple sequence alignment through sequence weighting, position-specific gap penalties and weight matrix choice. Nucl. Acids Res., 22, 4673-4680 (1994).

Vanegas, S.Z. and I. Agnarsson: DNA-barcoding of forensically important blow flies (Diptera: Calliphoridae) in the Caribbean Region. Peer J., 5, e3516 (2017).

Vargo, E.L. and C. Husseneder : Biology of subterranean termites: Insights from molecular studies of Reticulitermes and Coptotermes. Ann. Rev. Entomol., 54, 379-403 (2009).

Wang, C., X. Zhou, S. Li, M. Schwinghammer, M.E. Scharf, G. Buczkowski and G.W. Bennett: Survey and identification of termites (Isoptera: Rhinotermitidae) in Indiana. Ann. Entomol. Soc. Am., 102, 1029-1036 (2009).

Yeap, B.K., A.S. Othman, F.M. Dugal and C.Y. Lee : Genetic relationship between Coptotermes heimi and Coptotermes gestroi (Isoptera: Rhinotermitidae). Sociobiology, 56, 291-312 (2010).

Yeap, B.K., A.S. Othman, V.S. Lee and C.Y. Lee : Genetic relationship between Coptotermes gestroi and Coptotermes vastator (Isoptera: Rhinotermitidae). J. Econ Entomol., 100, 467-474 (2007). 